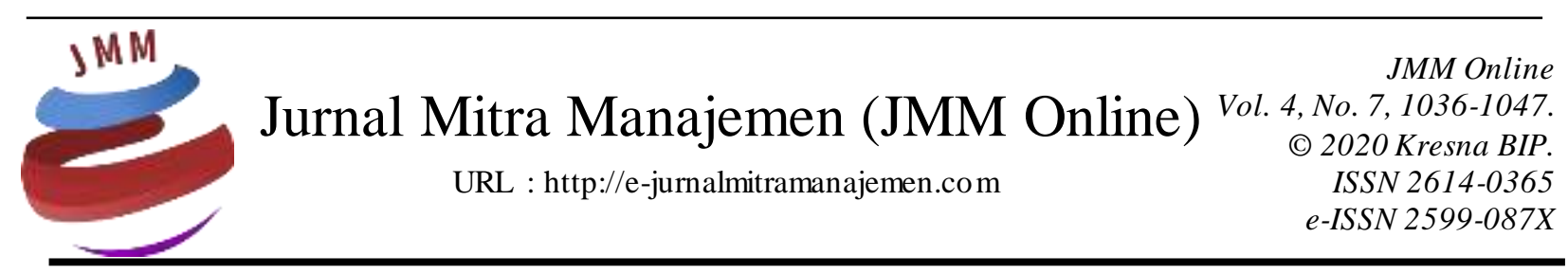

\title{
ANALISIS PEMASARAN MEDIA SOSIAL UNTUK MENENTUKAN INFLUENCER DAN TOPIK PEMBICARAAN (Studi Kasus: Go-Pay dan OVO)
}

\section{Assyifa Reska Sisilia ${ }^{1)}$, Refi Rifaldi Windya Giri ${ }^{2)}$ Universitas Telkom}

\section{INFORMASI ARTIKEL}

Dikirim : 07 Juli 2020

Revisi pertama : 09 Juli 2020

Diterima : 14 Juli 2020

Tersedia online: 04 Agustus 2020

Kata Kunci: E-Wallet, Pemasaran Pada Media Sosial, Social Network Analysis, Topic Modeling

Email : assyifareskal@gmail.com ${ }^{1)}$, rifaldi@telkomuniversity.ac.id ${ }^{2)}$

\section{ABSTRAK}

Perkembangan teknologi yang semakin pesat berdampak besar bagi kehidupan sehari-hari, termasuk pada sistem pembayaran. Sistem pembayaran yang menggunakan teknologi digital dapat mempermudah transaksi pembayaran secara non-tunai. Go-Pay dan OVO merupakan dua e-wallet terbaik sejak 2017. Ditengah persaingan yang semakin ketat Go-Pay dan OVO harus menerapkan strategi pemasaran pada media sosial. Media sosial merupakan platform yang memiliki sumber informasi mengenai pasar. Pada media sosial, perusahaan dapat menentukan akun dan topik yang dibicarakan oleh konsumen. Hasil penelitian memperlihatkan bahwa akun yang berpengaruh yaitu akun@ptinka,@alfamart, @bareksacomdantopikyang sering dibicarakan yaitu informasi, promo dan keluhan pelanggan. Berdasarkan hasil penelitian, perusahaan dapat memanfaatkan strategi pemasaran pada media sosial untuk memenuhi kebutuhan konsumen dengan meng gunakan metode social network analysis dan Topic Modeling. 


\section{PENDAHULUAN \\ Latar Belakang}

Perkembangan pengguna internet dari tahun ke tahun di Indonesia semakin meningkat, dengan meningkatnya pengguna internet dapat berdampak pada aspek bisnis salah satunya yaitu pada sistem pembayaran. Sistem pembayaran atau layanan transaksi saat ini telah menggunakan pembayaran digital seperti dompet digital atau $e$ wallet. E-wallet termasuk kedalam uang elektronik berbasis server (server-based). Ewallet muncul dengan sistem yang sudah terkoneksi dengan internet sehingga sangat memudahkan konsumen untuk menggunakannya. Transaksi uang elektronik di Indonesia selalu meningkat dari tahun ke tahun (BI, 2018). Jumlah transaksi yang meningkat juga berdampak pada persaingan penyedia produk uang elektronik yang semakin kompetitif serta kebutuhan akan uang elektronik yang akan meningkat (Salsabilaa \& Giri, 2017). Pada tahun 2017 persaingan pada $e$-wallet semakin ketat, perusahaan Go-Pay dan OVO berlomba-lomba untuk berada diposisi atas (iPrice, 2019). Berdasarkan data jumlah pengguna aktif dan jumlah pengunduh, Go-Pay dan OVO mengalami fluktuatif. Perusahaan yang mengalami fluktuatif dapat menganalisis untuk mencapai tujuan perusahaan dengan melihat dari sisi strategi pemasaran khususnya dibidang media sosial. Konsumen saat ini tidak mudah terpengaruh oleh kampanye pemasaran yang dilakukan oleh perusahaan, tetapi lebih mempercayai informasi pada media sosial (Kotler dkk, 2017). Oleh sebab itu, perusahaan perlu meningkatkan pemasarannya menggunakan media sosial dengan cara menentukan akun yang berpengaruh dan mengetahui topik yang sering menjadi perbincangan konsumen.

Media sosial merupakan platform yang memiliki sumber informasi mengenai pasar. Pada media sosial, perusahaan dapat menentukan akun dan topik yang dibicarakan oleh konsumen untuk merancang, mengelola dan mengoptimalkan strategi pemasaran. Salah satu yang termasuk media sosial yaitu Twitter. Twitter merupakan media sosial yang memiliki banyak pengguna sehingga memiliki data yang bersifat open source yang dapat dimanfaatkan dalam dunia bisnis (Wearesocial, 2018). Data twitter berukuran besar sehingga harus diolah menggunakan metode non-konvensional. Metode yang dapat digunakan adalah analisis jaringan sosial dan topic modeling. Perusahaan dapat memanfaatkan hal ini untuk mengetahui akun yang berpengaruh dan topik yang sering dibicarakan untuk masing-masing akun $e$-wallet. Metrik Centrality dapat digunakan untuk menentukan orang atau akun yang berpengaruh pada jaringan sosial. Berdasarkan uraian diatas, penulis memilih judul "Analisis Pemasaran Media Sosial Untuk Menentukan Influencer dan Topik Pembicaraan Menggunakan Social Network Analysis dan Topic Modeling (Studi kasus: Go-Pay dan OVO).

\section{Rumusan Masalah}

Go-Pay dan OVO telah sukses dalam meraih pasar $e$-wallet di Indonesia. Kesuksesan ini tidak akan terus bertahan jika Go-Pay dan OVO tidak terus menjaga konsistensi perusahaan dalam kegiatan bisnisnya. Tidak menutup kemungkinan kedepannya akan ada pesaing baru yang akan masuk dalam pangsa pasar $e$-wallet di Indonesia. Sehingga Go-Pay dan OVO harus menerapkan strategi pemasaran pada media sosial. Salah satu cara untuk menerapkan strategi pemasarannya adalah dengan 
menentukan akun yang berpengaruh pada jaringan sosial dan topik yang dibicarakan oleh konsumen agar dapat bertahan dalam industri jasa penyelenggara uang elektronik ketika diwaktu yang akan datang.

Salah satu metodenya yaitu dengan Social Network Analysis dan Topic Modeling. Keduanya dapat digunakan untuk menentukan akun yang berpengaruh pada jaringan dan topik yang dibicarakan oleh konsumen pada media sosial twitter terhadap Go-Pay dan OVO. Berdasarkan perumusan masalah yang telah disebutkan maka penulis menyusun pertanyaan penelitian sebagai berikut:

1. Siapakah yang akun yang berpengaruh dalam jaringan sosial Go-Pay dan OVO pada media sosial Twitter?

2. Apakah topik yang paling sering dibicarakan mengenai Go-Pay dan OVO pada media sosial Twitter?

\section{Tujuan Penelitian}

Berdasarkan perumusan masalah dan pertanyaan penelitian maka tujuan penelitian ini adalah sebagai berikut:

1. Untuk mengetahui akun yang berpengaruh mengenai Go-Pay dan OVO pada media sosial Twitter.

2. Untuk mengetahui topik yang paling sering dibicarakan mengenai Go-Pay dan OVO pada media sosial Twitter.

\section{KAJIAN PUSTAKA \\ Pemasaran Digital}

Pemasaran digital adalah istilah yang umum untuk pemasaran produk atau layanan yang menggunakan digital teknologi, terutama di Internet. Pemasaran digital mencakup semua upaya pemasaran yang menggunakan perangkat elektronik atau internet. Bisnis memanfaatkan saluran digital seperti mesin pencari, media sosial, $e$ mail, dan situs web lain untuk terhubung dengan konsumen saat ini dan calon konsumen (Smith dan Chaffey, 2017).

Smart Insight 2016 (dalam Chaffey dan Smith, 2017:14), berpendapat bahwa terdapat delapan aktifitas kunci pemasaran digital untuk merancang, mengelola dan mengoptimalkan aktifitas pemasaran sehingga menjadi kompetitif dan dapat memaksimalkan ROI. Salah satu kunci pemasaran digital yaitu pemasaran pada media sosial, yang dimana media sosial merupakan platform populer bagi konsumen dan pemasar karena menawarkan banyak peluang untuk berbagi ide, konten, dan rekomendasi merek.

\section{Pemasaran Media Sosial}

Pemasaran media sosial yaitu kegiatan online yang dirancang untuk melibatkan konsumen dimana secara langsung atau tidak langsung akan meningkatkan kesadaran, memperbaiki citra, atau memperoleh penjualan dari produk dan jasa. (Kotler \& Keller, 2016). Menurut (Kotler et.al., 2017:12) konsumen tidak lagi mudah terpengaruh oleh promosi pemasaran perusahaan, tetapi lebih mempercayai /tertarik dengan informasi pada media sosial baik keluarga, teman dekat bahkan orang yang tidak dikenalnya. 
Menurut Chaffey dan Smith (2017:247), untuk menyusun strategi pemasaran pada media sosial hal yang dilakukan pertama yaitu mendengarkan dan mengelola reputasi. Dengan mendengarkan percakapan di media sosial dan mengelola reputasi merek maka perusahaan akan meningkatkan pemahaman mendalam terhadap pemahaman pasar/topik yang sering dibicarakan dan identifikasi/menentukan akun yang berpengaruh (Influencer).

\section{Text Mining}

Text mining adalah teknologi yang mampu menganalisa data teks semiterstruktur maupun tidak terstruktur, sedangkan data mining mengolah data yang terstruktur (Han \& Kamber, 2012). Teks yang dilakukan pada proses text mining, pada umumnya memiliki beberapa karakteristik berdimensi tinggi, terdapat noise pada data, dan terdapat struktur teks yang tidak baik. Untuk mendapatkan bentuk data yang siap diproses oleh text mining, maka harus dilakukan text pre-processing terlebih dahulu dengan cara penyeleksian kata. Setiap kata dipecah menjadi bagian yang lebih kecil sehingga mempunyai arti yang lebih sempit.

\section{User Generated Content}

Menurut Moens, Li dan Chua (2014), User Generated Content adalah segala bentuk konten atau isi dalam sebuah media di dunia teknologi yang ada pada saat ini seperti blog, wiki, forum diskusi, chatting, tweet, podcasting, pin, gambar digital, video, file hingga berbagai bentuk konten media lainya yang terbentuk melalui buatan dari para pengguna sistem atau layanan online.

\section{Social Network Analysis}

Social Network Analysis dapat memodelkan hubungan sosial dengan node dan ties (edge, links, connection). Node adalah aktor individu yang berada didalam jaringan dan ties adalah hubungan antar node yang berbentuk garis (Kosorukoff, Alex, 2011).

\section{Topic Modeling}

Topic modeling adalah sebuah teori dan sebuah metode untuk mengekstrak serta merepresentasikan konteks dalam dokumen yang digunakan dengan memanfaatkan pengerjaan komputasi statistic untuk sejumlah corpus yang besar dari teks (Callaghan dkk, 2015).

\section{METODE PENELITIAN \\ Jenis Penelitian}

Penelitian dilakukan dengan metode kualitatif. Moleong (2012:4) mendefinisikan bahwa metodelogi kualitatif sebagai proses penelitian yang menghasilkan data deskriptif berupa kata-kata tertulis atau lisan dari orang-orang dan perilaku yang dapat diamati. Melalui penelitian kualitatif, penulis dapat mengenali subjek dan merasakan pengalaman mereka dalam kehidupan sehari-hari. Penelitian ini mengambil data dari cuitan yang terdapat pada twitter, karena banyak pengguna Twitter yang memberikan feedback mengenai Go-Pay dan OVO. Pola interaksi yang terbentuk akan memberikan pandangan baru dalam bisnis $e$-wallet di Indonesia. 
Tujuan dari penelitian ini bersifat deskriptif. Penelitian desktriptif digunakan untuk melihat gambaran faktor dan variabel, tanpa melakukan tes hubungan (Indrawati, 2015:115). Tujuan dari penelitian ini adalah untuk melihat siapa akun yang berpengaruh dalam jaringan interaksi pada media sosial khususnya twitter mengenai Go-Pay dan OVO, serta melihat apa topik yang sering dibicarakan dalam percakapan yang dibuat konsumen. Pada penelitian ini, penulis tidak melakukan intervensi pada data yang didapat (Indrawati 2015:117). Data yang diambil dan diolah oleh penulis merupakan data real yang didapat dari akun media sosial Go-Pay dan OVO pada twitter. Berdasarkan penelitian ini unit analisis yang digunakan adalah unit analisis kelompok dalam bentuk tweet dimana penulis akan menganalisis kelompok yang terbentuk berdasarkan hasil tweets yang didapatkan dari interaksi pengguna media sosial twitter terkait Go-Pay dan OVO. Berdasarkan waktu pelaksanaan penelitian, penelitian ini termasuk kedalam cross section. Metode cross sectional adalah metode yang dilakukan dalam satu periode waktu, kemudian data tersebut diolah dan dilakukan analisa dan dibuat kesimpulan hasil data tersebut (Indrawati, 2015:118).

\section{Objek Penelitian}

Objek penelitian ini adalah interaksi pengguna media sosial twitter mengenai Go-Pay dan OVO. Penelitian ini menggunakan keyword untuk memperoleh data yang sesuai dengan kriteria penelitian yang diambil pada 8 Januari 2020 s.d. 8 Februari 2020. Kata kunci yang digunakan yaitu "Go-Pay dan OVO" atau yang me-mention akun resmi Go-Pay dan OVO. Penelitian ini dilaksanakan pada bulan Desember 2019 hingga April 2020.

\section{Teknik Pengumpulan Data}

Jenis data yang digunakan dalam penelitian ini adalah data sekunder. Menurut Sugiyono (2017:137) menjelaskan bahwa data sekunder adalah sumber data yang tidak langsung memberikan data kepada pengumpul data. Data sekunder merupakan data yang sifatnya mendukung keperluan data primer seperti buku-buku, literatur dan bacaan yang berkaitan dan menunjang penelitian ini. Dalam penelitian ini, data sekunder diperoleh dari cuitan twitter mengenai e-wallet. Jenis data yang digunakan berupa arsip tweet yang diperoleh dari Twitter melalui twitter API. Data diambil dengan cara crawling menggunakan software Rstudio dan hasilnya berupa file dengan format CSV. Proses pengumpulan data dilakukan dengan cara crawling terkait dengan kata kunci, diantaranya yaitu "@gopayindonesia, gopay, Go-pay, \#pakaiGopay", “@ovo_id, \#promoOVO dan \#PakeOVOaja”.

\section{Teknik Analisis Data}

Analisis data dalam penelitian menggunakan metode Social Network Analysis Teknik Metrik Centrality. Centrality merupakan algoritma sentralitas yang digunakan untuk menemukan akun yang paling berpengaruh atau yang paling berperan dalam suatu jejaring. Centrality adalah hal paling mendasar dalam pengukuran Social Network Analysis (SNA). Terdapat empat matriks centrality yaitu Degree Centrality, Betwenness Centrality, Closeness Centrality dan Eigenvector Centrality. Sedangkan untuk Topic Modeling menggunakan teknik latent dirichlet allocation. Teknik ini 
dapat digunakan untuk merangkum, melakukan klasterisasi, menghubungkan maupun memproses data yang sangat besar karena LDA menghasilkan daftar topik yang diberi bobot untuk masing-masing dokumen. (Campbell, Joshua Charles,dkk 2015:139-159). Penelitian ini menggunakan software RStudio, Gephi dan Orange untuk mengolahnya.

\section{HASIL PENELITIAN DAN PEMBAHASAN}

\section{Hasil Penelitian}

Penelitian ini memperoleh 9.307 data tweet yang didapatkan dengan cara crawling menggunakan RStudio. Kemudian data diolah menggunakan Gephi untuk menentukan influencer dan Orange untuk mengetahui topik pembicaraan. Berikut adalah hasil pengolahan data tersebut.

\section{Menentukan Akun yang Berpengaruh pada Go-Pay dan OVO}

Gambar 1. Visualisasi SNA Go-Pay

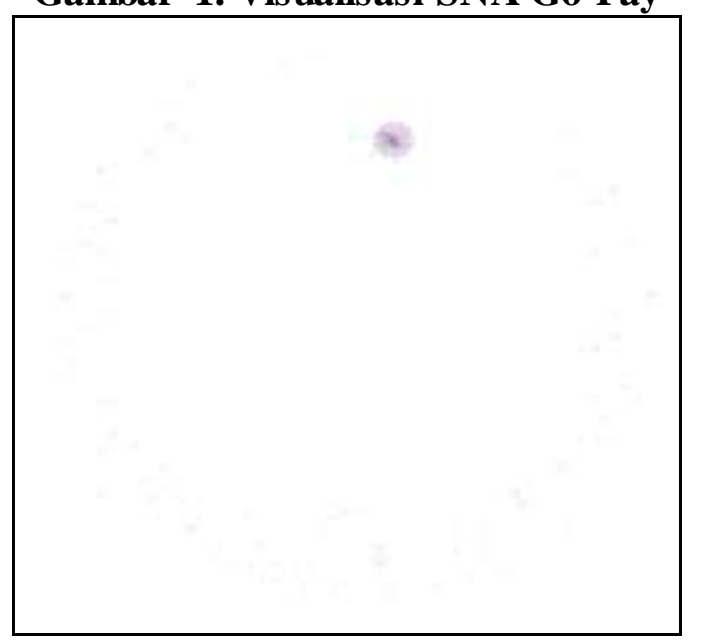

Sumber : Hasil Penelitian, diolah (2020)

Gambar 2. Visualisasi SNA OVO

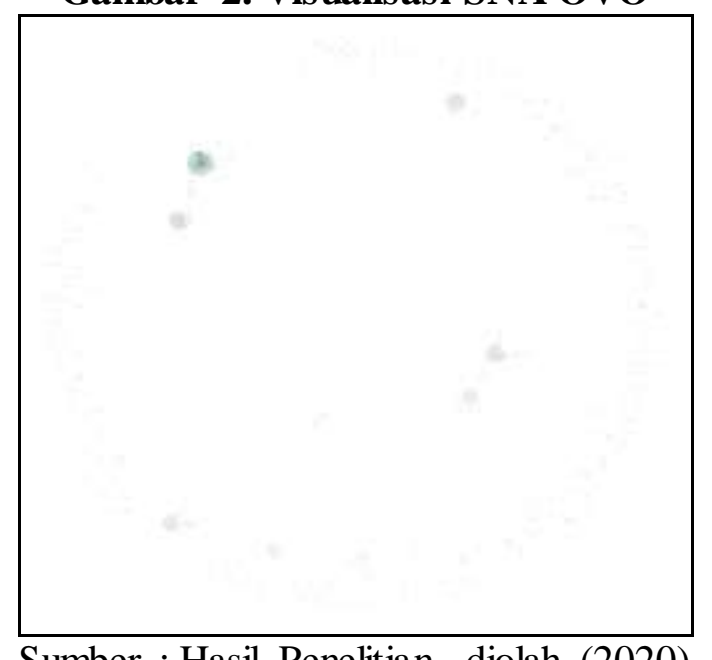

Sumber : Hasil Penelitian, diolah (2020) 
Berdasarkan gambar $1 \& 2$ diketahui bahwa terdapat hubungan antar akun yang ditunjukan pada tiga bentuk bulatan, sedangkan untuk yang di area jauh dari bulatan tersebut ialah akun yang tidak langsung berhubungan dengan akun-akun inti. Berikut ialah hasil pengukuran metrik pada akun Go-Pay.

Tabel 1. Hasil Pengukuran Metrik Centrality Go-Pay

\begin{tabular}{|l|l|l|l|c|l|c|c|c|}
\hline \multirow{2}{*}{ No } & \multicolumn{2}{|c|}{ Degree } & \multicolumn{2}{c|}{ Betwenness } & \multicolumn{2}{c|}{ Closeness } & \multicolumn{2}{c|}{ Eigenvector } \\
\cline { 2 - 8 } & Akun & B & \multicolumn{1}{c|}{ Akun } & B & \multicolumn{1}{c|}{ Akun } & B & Akun & Bobot \\
\hline 1. & ptinka & $\begin{array}{l}15 \\
7\end{array}$ & alfamart & 49 & alfamart & 0.69 & ptinka & 1.0 \\
\hline 2. & $\begin{array}{l}\text { gojekin } \\
\text { donesia }\end{array}$ & 13 & pulsa1com & 44 & pulsa1com & 0.69 & $\begin{array}{l}\text { gojekin } \\
\text { donesia }\end{array}$ & 0.92 \\
\hline 3. & $\begin{array}{l}\text { alfamar } \\
\text { t }\end{array}$ & 10 & _biant & 22 & $\begin{array}{l}\text { Aris_Koesj } \\
\text { ay }\end{array}$ & 0.67 & $\begin{array}{l}\text { alfamar } \\
\text { t }\end{array}$ & 0.91 \\
\hline 4. & _biant & 10 & $\begin{array}{l}\text { sahabatalfam } \\
\text { art }\end{array}$ & 9 & findayaindo & 0.67 & $\begin{array}{l}\text { pulsa1c } \\
\text { om }\end{array}$ & 0.74 \\
\hline 5. & $\begin{array}{l}\text { pulsa1c } \\
\text { om }\end{array}$ & 8 & Telkomsel & 8. & riprataksya & 0.67 & $\begin{array}{l}\text { Marku } \\
\text { sPutra }\end{array}$ & 0.64 \\
\hline
\end{tabular}

Sumber : Hasil Penelitian, diolah (2020)

Berikut ialah hasil pengukuran metrik pada akun OVO.

Tabel 2. Hasil Pengukuran Metrik Centrality Go-Pay

\begin{tabular}{|l|l|c|l|c|l|l|l|l|}
\hline \multirow{2}{*}{ No } & \multicolumn{2}{|c|}{ Degree } & \multicolumn{2}{c|}{ Betwenness } & \multicolumn{2}{c|}{ Closeness } & \multicolumn{2}{c|}{ Eigenvector } \\
\cline { 2 - 9 } & Akun & B & Akun & B & \multicolumn{1}{c|}{ Akun } & B & Akun & B \\
\hline 1. & ptinka & 158 & bareksacom & 253 & bareksacom & 0.85 & ptinka & 1.0 \\
\hline 2. & infak_id & 74 & GrabID & 64 & ngonlain & 0.83 & $\begin{array}{l}\text { bareksaco } \\
\text { m }\end{array}$ & 0.77 \\
\hline 3. & GrabID & 59 & kikysaputrii & 55 & $\begin{array}{l}\text { arie_febriant } \\
\text { o }\end{array}$ & 0.8 & GrabID & 0.45 \\
\hline 4. & $\begin{array}{l}\text { kikysaputr } \\
\text { ii }\end{array}$ & 56 & cheichaartic & 48 & teyosss & 0.8 & infak_id & 0.44 \\
\hline 5. & naaazzzs & 44 & $\begin{array}{l}\text { wardanaputr } \\
\text { a_ }\end{array}$ & 16 & $\begin{array}{l}\text { Marinakhaera } \\
\text { nii }\end{array}$ & 0.75 & $\begin{array}{l}\text { kikysaputr } \\
\text { ii }\end{array}$ & 0.39 \\
\hline
\end{tabular}

Sumber : Hasil Penelitian, diolah (2020)

\section{Menentukan Topik Pembicaraan Go-Pay dan OVO}

Topik pembicaraan pada Go-Pay dan OVO merupakan topik-topik pembicaraan yang muncul di media sosial supaya perusahaan dapat mengidentifikasi pelanggan yang membutuhkan informasi ataupun untuk meningkatkan penawaran produk dan layanan. Berikut lima topik teratas yang dimiliki oleh Go-pay dan OVO. 
Gambar 3. Lima Topik Teratas Go-pay

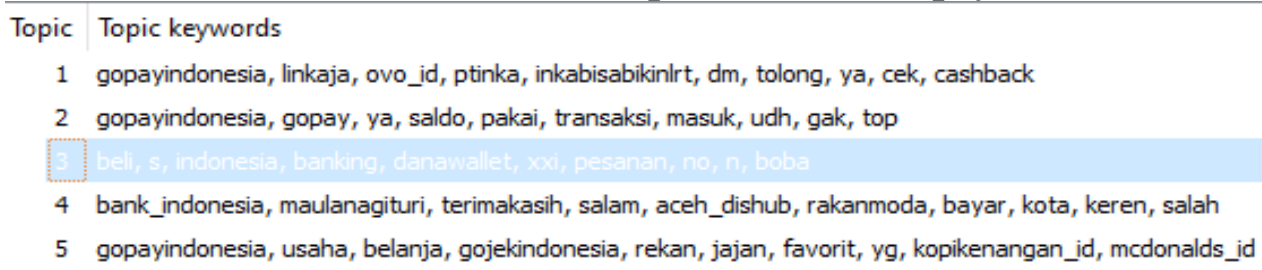

Sumber : Hasil Penelitian, diolah (2020)

\section{Topic Topic keywords}

\section{Gambar 4. Lima Topik Teratas OVO}

1 bareksacom, hai, pakeovodibareksa, bank_indonesia, maulanagituri, terimakasih, gampang, reksadana, isi, investasi

2 gopayindonesia, linkaja, kasih, keren, ptinka, bareksa, mantap, tinggal, inkabisabikinlrt, trans jogja

3 beli, transaksi, cashback, promo, bareksa, akun, reksadana, reksa, tp, praktis

4 ovo_id, ovo, dm, ya, cek, points, grabid, yg, langsung, sih

Sumber : Hasil Penelitian, diolah (2020)

Hasil topik pembicaraan diatas tersusun secara acak, sehingga perlu dilakukan interpretasi topik untuk dapat memahami topik pembicaraan. Berikut hasil interpretasi topik pembicaraan data.

Tabel 3. Interpretasi Topik Go-Pay

\begin{tabular}{|c|c|c|}
\hline Baris & $\begin{array}{r}\text { Interpretasi Topik } \\
\end{array}$ & Ket. \\
\hline & $\begin{array}{l}\text { @ ptinka dengan menggunakan hastag } \\
\text { \#inkabisabikinlrt memberikan giveaway dengan } \\
\text { memberikan saldo @ gopayindonesia @ linkaja atau } \\
\text { @ ovo_id. Pemenang diharapkan untuk dm akun } \\
\text { @ ptinka }\end{array}$ & Giveaway \\
\hline & $\begin{array}{l}\text { Beberapa akun memiliki keluhan kepada } \\
\text { @ gopayindonesia karena akun tersebut telah } \\
\text { melakukan transaksi top up saldo tetapi tidak ada } \\
\text { penambahan saldo pada Go-Pay. Topik kedua yaitu } \\
\text { @ gopayindonesia memberikan promo jika bayar } \\
\text { pakai Go-Pay, dapat menikmati cashback untuk } \\
\text { membeli Krispy Kreme, Laka-laka dan Secure } \\
\text { Parking. }\end{array}$ & $\begin{array}{l}\text { Keluhan } \\
\text { dan Promo }\end{array}$ \\
\hline & $\begin{array}{l}\text { Pelanggan yang melakukan top up saldo melalui } \\
\text { m-banking terdapat kendala yaitu saldo pada bank } \\
\text { sudah terpotong tetapi tidak ada penambahan pada } \\
\text { saldo Go-Pay. @ gopayindonesia memberikan } \\
\text { cashback yaitu Spesial Imlek Go-Pay di XXI pada } \\
\text { tanggal 24-27 Januari } 2020 \text { dan pembelian Brown } \\
\text { Sugar Boba hingga tanggal 31 Januari } 2020\end{array}$ & $\begin{array}{l}\text { Keluhan } \\
\text { dan Promo }\end{array}$ \\
\hline
\end{tabular}


Lanjutan Tabel 3. Interpretasi Topik Go-Pay

\begin{tabular}{|c|c|c|}
\hline Baris & Interpretasi Topik & Ket. \\
\hline & $\begin{array}{l}\text { @ maulanagituri berterimakasih } r \\
\text { @ bank_indonesia karena dengan QRIS, Tidak ada } \\
\text { lagi ekslusifitas dalam pembayaran. Sekarang } \\
\text { vending machine yang dahulu harus menggunakan } \\
\text { aplikasinya sendiri. Sekarang dengan mudahnya } \\
\text { dapat melakukan pembayaran menggunakan Go- } \\
\text { Pay/ovo/linkaja dan terdapat informasi yang } \\
\text { disampaikan oleh akun @aceh_dishub mengenai } \\
\text { masyarakat yang ingin menyebrang ke Sabang } \\
\text { menggunakan kapal cepat dapat membayar tiket } \\
\text { pakai Go-Pay. }\end{array}$ & Informasi \\
\hline & $\begin{array}{l}\text { Kalo masyarakat ingin jajan atau belanja di Rekan } \\
\text { Usaha favorit, dapat scan pakai Go-Pay pada kode } \\
\text { QR bertuliskan QRIS!QRIS alias Quick Response } \\
\text { QR Code Indonesia Standard, diluncurkan Bank } \\
\text { Indonesia pada } 17 \text { Agustus } 2019 \text { lalu buat semua } \\
\text { Penyedia Jasa Sistem Pembayaran (PJSP) berbasis } \\
\text { kode QR, termasuk Go-Pay. Cara pakainya seperti } \\
\text { biasa kalau kamu jajan dan belanja pakai Go-Pay. } \\
\text { Dan pada topik selanjutnya terdapat keluhan } \\
\text { mengenai pemesanan @ kopikenangan_id dan } \\
\text { medonalds_id yaitu saldo telah terpotong tetapi } \\
\text { pesanan gagal atau dibatalkan. }\end{array}$ & $\begin{array}{l}\text { Informasi } \\
\text { dan } \\
\text { Keluhan }\end{array}$ \\
\hline
\end{tabular}

Sumber : Hasil Penelitian, diolah (2020)

Tabel 4. Interpretasi Topik OVO

\begin{tabular}{|c|c|c|}
\hline Baris & Interpretasi Topik & Ket. \\
\hline & $\begin{array}{l}\text { @bareksacom merupakan akun marketplace } \\
\text { untuk investasi reksadana online yang } \\
\text { berkolaborasi dengan ovo dan mempunyai hastag } \\
\text { khusus yaitu \#pakeovodibareksa dan } \\
\text { @maulanagituri berterimakasih r kepada } \\
\text { @bank_indonesia karena dengan QRIS, Tidak } \\
\text { ada lagi ekslusifitas dalam pembayaran. Sekarang } \\
\text { vending machine yang dahulu harus } \\
\text { menggunakan aplikasinya sendiri. Sekarang } \\
\text { dengan mudahnya dapat melakukan pembayaran } \\
\text { menggunakan Go-Pay/ovo/linkaja }\end{array}$ & $\begin{array}{l}\text { Promo dan } \\
\text { Informasi }\end{array}$ \\
\hline
\end{tabular}


Lanjutan Tabel 4. Interpretasi Topik OVO

\begin{tabular}{|c|c|c|}
\hline Baris & $\begin{array}{c}\text { Interpretasi Topik } \\
\end{array}$ & Ket. \\
\hline & $\begin{array}{l}\text { @ ptinka dengan menggunakan hastag } \\
\text { \#inkabisabikinlrt memberikan giveaway dengan } \\
\text { memberikan saldo @ gopayindonesia @ linkaja } \\
\text { atau@ @ovo_id. Pemenang diharapkan untuk dm } \\
\text { akun @ ptinka. Selanjutnya terdapat topik } \\
\text { mengenai bareksa yang memberikan promo jika } \\
\text { melakukan pembayaran reksadana melalui OVO. } \\
\text { Dan terdapat informasi mengenai @ trans_jogja } \\
\text { yang telah menggunakan mesin device baru yang } \\
\text { dapat melakukan pembayaran melalui ovo, Go- } \\
\text { Pay dan linkaja. }\end{array}$ & $\begin{array}{l}\text { Giveaway, } \\
\text { Promo dan } \\
\text { Informasi }\end{array}$ \\
\hline & $\begin{array}{l}\text { @ bareksacom merupakan akun marketplace } \\
\text { untuk investasi reksadana online yang } \\
\text { berkolaborasi dengan ovo dan mempunyai hastag } \\
\text { khusus yaitu \#pakeovodibareksa. Jika pelanggan } \\
\text { melakukan pembayaran reksadana menggunakan } \\
\text { ovo akan mendapatkan cashback }\end{array}$ & Promo \\
\hline & $\begin{array}{l}\text { Beberapa akun me-mention @ ovo_id dan } \\
@ \text { grabid karena tidak dapat menggunakan ovo } \\
\text { point untuk pembayaran dan jarang terdapat } \\
\text { cashback lagi. }\end{array}$ & Keluhan \\
\hline & $\begin{array}{l}\text { Pembayaran menggunakan aplikasi ovo untuk } \\
\text { invest di@bareksacom, berdonasi ke Rumah } \\
\text { Zakat lebih mudah dan cepat walaupun terkadang } \\
\text { memiliki kendala. Akun yang memiliki keluhan } \\
\text { atau pertanyaan akan langsung dm akun resmi } \\
\text { ovo/grab. Selanjutnya akun @ ridermerah menjadi } \\
\text { topik pembicaraan karena akun tersebut memiliki } \\
\text { jumlah OVO Point yang terbilang banyak. }\end{array}$ & $\begin{array}{l}\text { Informasi } \\
\text { dan keluhan }\end{array}$ \\
\hline
\end{tabular}

Sumber : Hasil Penelitian, diolah (2020)

\section{Pembahasan}

1. Go-pay

Berdasarkan hasil pengolahan data, akun yang berpengaruh pada jaringan sosial Go-pay adalah akun @ ptinka dan@alfamart. Akun@ptinka adalah akun dibidang jasa transportasi yang sering membagikan saldo berupa uang elektronik salah satunya yaitu Go-pay sedangkan akun @alfamart yaitu akun mitra go-pay sebagai alat pembayaran elektronik. Akun @ptinka dan @alfamart memiliki pengaruh yang tinggi, menjadi penghubung dalam jaringan, memiliki kecepatan dalam menyebarkan informasi dan memiliki performa yang paling baik dalam jaringan sosial. Topik pembicaraan yang sering muncul ialah berupa keluhan terhadap layanan, promo dan informasi. 


\section{OVO}

Berdasarkan hasil data yang telah diolah, akun @ptinka dan @bareksacom merupakan akun yang berpengaruh pada jaringan sosial OVO. Akun @ptinka sering mengadakan giveaway berupa saldo OVO dan akun @bareksacom nenberikan cashback kepada konsumen yang investasi menggunakan OVO. Topik pembicaraan yang sering dibicarakan atau sering muncul yaitu mengenai promo, informasi dan keluhan pelanggan terhadap layanan.

\section{KESIMPULAN DAN SARAN Kesimpulan}

Akun yang sangat berpengaruh pada media sosial yaitu@ptinka dan@alfamart untuk Go-pay, @ptinka dan @bareksacom untuk OVO, Hal ini menyatakan bahwa akun@ptinka, @alfamart, @bareksacom merupakan akun yang berpengaruh yang dapat menjadi jembatan interaksi antar akun, memiliki kecepatan dalam menyebarkan informasi dan memiliki keterikatan dengan banyak akun penting pada jaringan sosial Go-Pay dan OVO di media sosial Twitter.

Topik pembicaraan yang banyak muncul yaitu mengenai giveaway, informasi, promo dan ketidaknyamanan dalam penggunaan layanan.

\section{Saran}

1. Bagi penelitian selanjutnya diharapkan dapat melakukan penelitian menentukan akun yang berpengaruh / influencer pada perusahaan $e$-wallet yang berbeda ataupun influencer pada bidang lainnya.

2. Seiring dengan perkembangan teknologi diharapkan pada penelitian selanjutnya dapat menggunakan alat analisis yang baru dalam menganalisis hal yang sama dikemudian hari.

3. Perusahaan e-wallet Go-Pay dan OVO dapat melihat akun/influencer yang berpengaruh berdasarkan nilai masing-masing metrik. Sehingga dapat melakukan endorsement atau kerjasama kepada akun yang memiliki nilai pengukuran tertinggi dan aktif di media sosial untuk menyebarkan informasi.

4. Topic modeling dapat digunakan sebagai informasi untuk mengetahui topik yang paling banyak dibicarakan oleh konsumen dan dapat diketahui topik yang menarik dan menjadi perhatian mengenai Go-Pay dan OVO. Dengan begitu, perusahaan penerbit uang elektronik dapat mengembangkan dan meningkatakan produk atau layanan sesuai dengan pengalam pelanggannya.

\section{DAFTAR PUSTAKA}

Bank Indonesia. 2018. Transaksi Uang Elektronik. Retrieved from Statistik Sistem Pembayaran: https:/www.bi.go.id/id/statistik/sistem-pembayaran/uangelektronik/contents/transaksi.aspx. [Diakses pada 12 September 2019]

Callaghan, O, Derek., Green, Derek., Carthy, Joe., Cunningham, Padaraig. 2015. An Analysis of the Coherence of Descriptors in Topic modeling. Expert System with Application.42. ElSevier.

Campbell, Joshua Charles,dkk. 2015. Latent Dirichlet Allocation: Extracting Topics. The Art and Science of Analyzing Software Data Pages 139-159 
Han, J.W., Kamber, M. and Pei, J. 2012. Data Mining Concepts and Techniques. 3rd Edition, Morgan Kaufmann Publishers, Waltham

Indrawati. 2015. Metode Penelitian dan Bisnis: Konvergensi Teknologi Komunikasi dan Informasi. Bandung: Refika Aditama

Kotler, Phillip dan Keller, Kevin Lane. 2016. Marketing Management. 15th Edition. Pearson Pretice Hall.

Kotler, Phillip. Kartajaya, Hermwan. dan Setiawan, Iwan. 2017. Marketing 4.0: Moving from Traditional to Digital. Publish: Simultaneously in Canada.

Kosorukoff, Alex. 2011. Social Network Analysis: Theory and Applications. Passmore, D. L, 2011

Moens, M. F., Li, J., \& Chua, T. S. 2014. Mining User Generated Content. New York: CRC Press

Oktora, Rio dan Alamsyah, Andry. 2014. Pola Interaksi dan Aktor yang Paling Berperan Pada Event JGTC 2013 Melalui Media Sosial Twitter (Studi Menggunakan Metode SNA); Jurnal Manajemen Indonesia)

Salsabila, Nisa; Giri, Refi Rifaldi. 2017. Peta Positioning Uang Elektronik Berdasarkan Persepsi Masyarakat di Indonesia Tahun 2017. Jurnal Riset Bisnis Dan Manajemen, [S.L.], V. 10, N. 2, P. 34-41, Sep. 2017. Issn 2580-9539.

Smith, PR., dan Chaffey, Dave. 2017. Digital Marketing Excellence Planning, Optimizing and Integrating Online Marketing. 5thEdition. Routledge: NewYork

Sugiyono. 2017. Metode Penelitian Kuantitatif, Kualitatif, dan R\&D. Bandung: Alfabeta.

Vivin Dian Devita. 2019. Siapa Aplikasi E-wallet dengan Pengguna Terbanyak di Indonesia?.iprice.co.id.[online].Tersedia:https://iprice.co.id/trend/insights/ewallet-terbaik-di-indonesia/. [Diakses pada 10 September 2019]

Wearesocial. 2018. Global Digital Report 2018. wearesocial.com. [online]. Tersedia: https:/digitalreport.wearesocial.com/. [Diakses pada 30 Oktober 2019] 